\title{
Focusing on Poverty Alleviation to Secure a Decisive Victory in Building a Moderately Prosperous Society in all Respects
}

\author{
-Based on Targeted Poverty Alleviation in Hunan Province
}

\author{
Wen Wei \\ Marxism College (Mao Zedong College) \\ Xiangtan University \\ Xiangtan, Hunan, 411105
}

\begin{abstract}
Poverty alleviation is the key and difficult point as well as the focus of the Party to lead people to secure a decisive victory in building a moderately prosperous society in all respects and realize the first "Centenary Goal". It is also the top priority of Party and governmental work in Hunan province. Therefore, in order to build a moderately prosperous society in all respects, Hunan must grasp the core of poverty alleviation, unit all wisdom and forces, thoroughly implement the strategic deployment by Central government on targeted poverty alleviation and take further step to strengthen organizational leadership, improve targe ted mechanism, intensify infrastructure and address the weakest links in the development. In addition, it must do each work in a more accurate and precise manner and comple te the glorious but arduous task on time which ensures those who live in poor villages and counties will be out of poverty and lifts all of its poor out of poverty.
\end{abstract}

Keywords-poverty alleviation, targeted poverty alleviation, be lifted out of poverty, a moderately prosperous society in all respects

Since general secretary Xi Jinping first proposed 'targeted poverty alleviation" during his visit to Huayuan County on November 3, 2013, Hunan province thoroughly implements the strategic deployment by Central government on targeted poverty alleviation, aims to build a moderately prosperous society in all respects, focuses on accurate recognition of poverty alleviation and takes targeted measures to help people lift themselves out of poverty. Moreover, it insists on the combination of inclusive policy and preferential policy and the connection between the poverty alleviation policies and social security system, intensifies governmental leadership, improves the mechanism of targeted poverty alleviation, strengthens infrastructure, and addresses the weakest link, thus building the great pattern of poverty alleviation promoted by the government, the society and the market, making significant progress in targeted poverty alleviation in the province and laying a solid foundation for building a moderately prosperous society in all respects in Hunan. However, at present, Hunan province encounters many problems and difficulties in helping people lift themselves out of poverty. It is an arduous task. By 2020, 3.31 million poor people will be lifted out of poverty and over 1.10 million people will be helped to lift themselves out of poverty every year, which is an arduous task with limited time. In addition, it should ensure that poor people in Hunan province can get out of poverty in time and poor counties will be out of poverty by 2020. It must find specific ways to successfully realize a moderately prosperous society in all respects. Therefore, we must first analyze the difficulties and problems in poverty alleviation.

\section{IN-DEPTH ANALYSIS OF DIFFICULTIES AND PROBLEMS IN POVERTY ALLEVIATION}

As we all know, China's large-scale exploration of poverty alleviation starts with Hunan province and then spreads to the whole country. In 1984, firstly declaring war to poverty, Hunan launched poverty alleviation and implemented organized and planned exploration of poverty alleviation in a creative manner. Together with the people over all the country, Hunan blazed a new trail in poverty alleviation with Chinese characteristics which combines social support with main role of farmers, inclusive policy with preferential policy and development-oriented poverty reduction and social security driven by economic development and led by the government with strengthening the ability of self-development of those living under the poverty line as the basic way, thus realizing transition from relief-oriented poverty alleviation, to development-oriented poverty alleviation to innovation and development-oriented poverty alleviation and making substantial achievements in poverty alleviation. According to statistics of Hunan Leading Group Office of Poverty Alleviation and Development, in 2016, 1.25 million poor people in Hunan province have been lifted out of poverty and 1,053 poor villages have been out of poverty. [1] However, there are some difficulties and problems in targeted poverty alleviation in Hunan province that cannot be ignored.

First, imprecision of poverty alleviation. The result of accurate recognition of poverty alleviation cannot perfectly match with the reality of poor households in some places. For example, in some places, some poor households have houses and cars, some poor households are very lazy and some poor households have relationship with some administrators. And real poor households haven't yet obtained support of poverty alleviation. Thus there are lots of complaints among the mass. The reason why there is such phenomenon is that it is hard to 
recognize farmers' diversified and immeasurable incomes. Besides, the information on poverty alleviation is not accurate and grass-roots cadres lack principles, fairness and justness.

Second, cadres at the grass-roots lack a strong sense of responsibility. In few towns and villages, especially the latter, cadres are short of the initiative and enthusiasm to bring the poor out of poverty. They fail to implement the policy and remove that last crucial hurdle ${ }^{[1]}$. The reason of this phenomenon is that some cadres still poorly understand the importance of targeted poverty alleviation. For example, some lack enthusiasm, believing it is difficult to show their achievements, whereas some think it is none of their business and choose to ignore.

Third, we need to deepen the construction of work style. Cadres in few spots are so impatient that increase the poverty alleviation mission without restriction; some just propaganda the policy and do nothing; some just deal with the matter, instead of suiting measures to different conditions in terms of issue and people concerned[1]. The cause of the problems is: the agencies in cities and counties are low-ranking with few staff; workers in these agencies face lots of resistance with poor salary.

Fourthly, our work progress is not balanced enough. There are significant differences between county and county, town and town, village and village. Disparity also exits in performance among relevant departments. It is universal that some cadres only emphasize on poverty alleviation, but ignore to consolidate the gains ${ }^{[1]}$. That is because leaders at all level give different attention.

Fifth, Funds are not effectively used. Some cadres spend the money without actually helping the poor, which leads to no obvious benefits; some do not spend the money on development; some even idle the fund ${ }^{[1]}$.

Six, the foundation work is not solid. Some places fail to fill and submit correct and up-to-date information. There is discrepancy between system information and reality. The poverty identification in some places is a mere formality, while the mass know nothing and disagree. Some places even lack strict procedures and standard data ${ }^{[1]}$.

One of the main reasons of above problem is that we attach insufficient importance to the targeted poverty alleviation. Therefore, we must recognize its significant meaning, in order to solve the problem fundamentally and ensure that Hunan can realize a well-off society in an all-round way by 2020 .

\section{Understand the Great Significance of Poverty ALLEVIATION}

Currently, the party leads the people to win a comprehensive well-off life and realize the first Centenary Goal, and poverty alleviation is the top priority, difficulty and focus. Meanwhile, it's also remains the top priority of the party and government work of Hunan province.

A. Winning a comprehensive well-off society requires the victory of the battle against the poverty

Building a moderately prosperous society is an important part of the Four-Pronged Comprehensive Strategy. Meanwhile, it's also the strategic goal, fundamental direction and action platform for the party to lead our people in establishing socialism with Chinese characteristics. A well-off society in all-round way can benefit all the people. Xi Jinping emphasized that "we won't reach the goal of winning a comprehensive well-off society without the rural prosperity, especially in the poor areas." "2] Since the founding of new China, under the leadership of the CPC, we have traveled on a road of eliminating poverty with Chinese characteristics. In particular, through more than 30 years of reform and opening-up, China has succeeding in lifting more than 700 million people out of poverty. Free and compulsory education and higher education have been popularized in all aspects. Besides, we have built the world's largest basic medical care and the old-age security system, which makes great contributions to the world's poverty reduction. However, the current situation of poverty alleviation in China is still grim, and helping the poor people out of poverty has become the most difficult task of building a comprehensive well-off society. In order to accomplish the task of lifting 3.31 million poor people out of poverty in three years, Hunan province must concentrate its efforts on overcoming difficulties and resolutely tackle the tough issue of poverty alleviation. Therefore, we can win the battle against poverty and contribute Hunan effort to the success of establishing a comprehensive well-off society.

\section{B. Fulfilling the party's solemn commitment to win the battle against poverty}

Poverty alleviation is a major strategy made by the CPC and the State Council. It's also an important part of implementing the concept of Shared Development, a prerequisite for building socialist harmonious society and a guarantee for achieving a well-off society. Meanwhile, poverty alleviation is even a solemn commitment made by the party to the whole nation. On the afternoon of February 21, 2017, General Secretary Xi Jinping presided over the 39th studying meeting of the political bureau of the CPC central committee, discussing the situation of China's poverty alleviation and the better implementations. Xi stressed, "Promises must be kept and actions must be resolute. Lifting the rural poor out of poverty, helping all the poor counties to be prosperous and addressing overall regional poverty are the bottom line tasks of building a comprehensive well-off society, meanwhile these are solemn commitments we have made to our people." General Secretary Xi's speech fully demonstrated a strong confidence of the party to win the battle against poverty. Meanwhile this speech blew the horn for all government departments and party members to complete the task of poverty alleviation. Only when we win the battle against poverty, the poor can get rid of poverty and poor counties can escape the cycle of poverty as scheduled. Therefore, we must try every means, and assemble all wisdom and strength to overcome difficulties and win the battle against poverty.

\section{To achieve common prosperity, we must win the hard battle against poverty}

Eliminating poverty, improving people's livelihood and achieving common prosperity are the essential requirements of socialism and the important mission of the party. Mao Zedong had repeatedly stressed that to realize common wealth, we must follow the socialist road. "Only unite and advance toward 
the socialist road, can the majority of peasants in the country get rid of poverty, improve their lives and resist the famine"; ${ }^{[3]}$

"To consolidate the alliance of workers and peasants, we must lead the peasants to take the socialist road, so that the poor peasants can become rich, and the degree of prosperity should be much greater than that of the current wealthy peasants." ${ }^{[4]}$ Deng Xiaoping emphasized that common prosperity is the greatest superiority of socialism. "Compared with capitalism, socialism is characterized by common prosperity and non-polarization." [5] Xi Jinping pointed out that if poor areas are chronically poor without change, and the masses' lives haven't been significantly improved for a long time, then superiority of China's socialist system doesn't work out and it is not socialism. [6] If the poverty and backwardness of poverty-stricken areas have not been changed for a long time, the poor will be in a state of poverty for a long time. This doesn't reflect the superiority of the socialist system, and may even result in damaging the foundation of the long-term governance of the Communist Party and endanger the long-term stability of the country. Therefore, we must win the fight against poverty and fundamentally change this backwardness.

\section{STRENGTHEN THE PLAN OF POVERTY ALLEVIATION PROGRAM}

Government above county level can make poverty alleviation that conforms to reality and satisfy regional development and industrial development, according to "Hunan Province's 'Thirteenth Five-Year Plan' for Poverty Alleviation”. When making plan for specific item, provincial, municipal and county departments should take into consideration the poverty alleviation. Counties, townships, and villages should formulate annual poverty alleviation implementation plan, and advance it in an orderly manner to ensure that actual work follow closely with planning. In accordance with the principle of "unified planning, constant channel, centralized use, and practical results", we will concentrate on solving the outstanding problems of poor villages and poor people and improve the effectiveness of poverty alleviation.

\section{A. Make innovations on mechanism of poverty alleviation}

Establish a mechanism for poverty alleviation that contains dynamic management, capital project management and assessment and evaluation incentives, integrates poverty alleviation resource, and allows the poor to participate in. Implementing accurate poverty identification by checking that who are really in need, what causes poverty, and the types of poverty, and deleting all kinds of fake "poor households" to help the poor. Improve the establishment of archives, building a big data platform for poverty alleviation in Hunan. Carry out the dynamic management of poverty-stricken population by writing off those who have shaken off poverty and imputing the one that returns to poverty. Moreover, strictly implement the poverty exit criteria and exiting procedures, in case of just number reducing and fake poverty alleviation. Prevent people returning to poverty alongside the work of poverty reduction and consolidate the effectiveness of poverty alleviation. Integrate various poverty alleviation funds and projects and allocate most of them to poverty-stricken areas, and implement them in poor villages and poor households to solve the funding and project needs of the poor. Enhance the management of various poverty alleviation funds and projects, and improve the integration of poverty-stricken counties' agriculture-related funds. Make sure the fiscal funds are allocated to specific village and households and improve audit's capability to identify mistakes. Improve the accountability system for the use of poverty alleviation funds, and severely punish those who violate laws and regulations in the poverty alleviation. All these measures can contribute to the safe, effective and accurate use of funds. Fully mobilize the poor to take off the initiative and enthusiasm to lift themselves out of poverty. Implement poverty fighting performance and unit performance evaluation for the selection and use of cadres, so as to enhance the sense of responsibility of cadres tackling poverty, improve the effectiveness of tackling poverty.

\section{B. Accurately implement policies and measures to combat poverty}

(1) Specific poverty alleviation: First, we must do a good job in getting rid of poverty in the industry. Second, we can achieve poverty alleviation by microfinance, that is, increase the amount of loans and the quality of loans, and launch the "Fupin Tehui Insurance" to help enterprises in poor areas to go public. Third, we can get rid of poverty through labor service cooperation, that is, help those who are willing to go out to work to get rid of poverty through labor cooperation. Fourth, we must do a good job in relocation and renovation of dilapidated buildings to complete the task of relocation and poverty alleviation. (2) Poverty alleviation in the industries: First, we must promote education out of poverty. Second, we must promote health and poverty alleviation. Focus on helping a number of public hospitals in poor counties, poor township health centers, and clinics in poor villages. Third, we must push forward the poverty-stricken village upgrading project, determine the construction content and standards according to local conditions, and avoid imposing uniformity in all cases. Fourth, we must promote the integration of rural low-income standards and poverty alleviation standards, and provide subsistence or work for eligible poor people such as low-income households and households enjoying the five guarantees. (3) Social poverty alleviation: we can build a social poverty alleviation work platform to guide all walks of life to actively participate in poverty alleviation in Hunan Province, transforming the previous donation to help them create wealth by themselves, so as to improve the sense of satisfaction of the poor.

\section{Go all out in implementation of targeted poverty alleviation}

(1) Responsibility for poverty alleviation must be cleared, in which party committees and governments at all levels should sign and implement duty agreement, leading and setting examples for each other to ensure poverty reduction. (2) Officials should be encouraged to station in villages and partner with people there. Incentive system for cadres stationed in villages, including compensation package, must be established and then perfected. Meanwhile, cadres should improve their leadership accordingly. Pair-share between cadres and poor households in the same unit are mobilized to guarantee individualized help, policy and responsible person. 
(3) Tasks of poverty alleviation should be timely broke down and delivered to counties, villages, and township to ensure solid implementation, solving poverty at its source and offering people practical help. (4) Clear governance should be built in the process. Officials must enhance case investigation and handling, especially to those prohibited behaviors, such as fraudulent application and claim, withholding and privately division, briberies asking, making profit for relatives and friends, and competing with the private. Incorrupt education should be deepened to lay deterrent effect on corruption so that people will not dare to, not want to and cannot corrupt. (5) Supervision and inspect system must be consolidated. Comprehensive and special supervision, open and secret investigation should be combined with the masses reports. Enhanced supervision on poverty alleviation fund and support measures should be implemented in place, especially in those problematic cities and towns. Only when supervision team investigate openly and secretly, direct report system timely feedback and fix problems can we overcome poverty. (6) Examination and estimation should be strictly conducted. Notification, interview and accountability must take effect on those who are derelict of duty, favor formalism and counterfeit, while commend and reward should also be utilized to promote responsibility realization.
At present, poverty alleviation has entered the critical stage. Hunan Province must work with the people across the country, under the leadership of the party, to gather all wisdom and strength to strengthen the guide of poverty alleviation planning, innovate the mechanism of poverty alleviation, and accurately implement poverty alleviation policies and measures. Concentrate on the precise implementation of poverty alleviation, to complete the task as scheduled, and build a well-off society in an all-round way.

\section{REFERENCES}

[1] Hunan Poverty Relief Office: 2016 Hunan Targeted Poverty Alleviation Report and 2017 Outlook, 2017 Hunan Blue Book.

[2] Xi Jinping: Become a County Clerk Like Jiao Yulu-style, Beijing: CCCPC Party Literature Publishing House, 2015.16

[3] Mao Zedong Collected Works [M].Beijing: People’s Publishing House, 1999.429.

[4] Literature research office of CPC central committee. Important documents since the founding of the People's Republic of China: Volume 7 [M]. Beijing: CCCPC Party Literature Publishing House, 1993.308

[5] Deng Xiaoping Selected Works, III [M]. Beijing: People’ s Publishing House, 1993.123

[6] Propaganda Department of the Communist Party of China: General Secretary Xi Jinping important speech series, Xuexi Publishing House, People’s Publishing House 2016.219. 